\title{
Study of HemolysinTitre in 'O' Group Donors
}

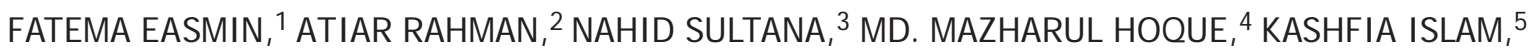 \\ SONIA SHORMI NM, ${ }^{6}$ J OLLY BI SWAS ${ }^{7}$
}

\begin{abstract}
Summary: Antibodies are globulins which are produced in response to an antigenicstimulation. The antibody that activates complement leading to cell lysis is calledhemolysin antibody. Group ' $O$ ' donor's plasma may contain potent anti $A$ or anti-B, capable of reacting with the red cells ofgroup $A, B$ or $A B$ recipent and sometimescause $a$ severe transfusion reaction. The anitbodies may take the form of high titre agglutinins or hemolysins. Patient's blood group $A, B$ or $A B$ receiving " $O$ " blood groupwith a high titre $\lg G$ anti- $A$ or anti-B reacting at $37^{\circ} \mathrm{C}$ may experience a moderatetransfusion reaction resulting jaundice and progressive anaemia. Immune anti-A and anti$B$ are sometimes responsible for transfusion reaction.
\end{abstract}

Objective: To find out the haemolysintitre of "O" blood group female donor.

Methods: This cross sectional study was done on 100 cases of ' $O$ ' blood group female inchild bearing age and 100 adult male was selected as control, in transfusion medicine department, BSMMU from June 2008 to May 2009. Detailed demographic and clinical findings of all subject were recorded in data collection sheet,all analysis was done using SPSS (statistical package for social science)

Result: The mean age differences was found statistically significant $(P<0.5)$ between female \& male, 81 ( $81.0 \%)$ had $R h+$ ve \& $19 \%$ had in negative female subject. $94 \%$ hadhaemolytic test positive in female and $8 \%$ had haemolysin test positive in male subject.The mean haemolysin antibody with A cell was $2.13 \pm 12.3$ and with $B$ cell was $16.5 \pm 8.15$.

Conclusion: It is important to avoid transfusion of blood containing high titres ofimmune anti $A$ and anti $B$ antibodies to non $O$ group recipients, strongly heamolytic samples have high titres of $l g G$, a simple screen for donor heamolysin is suggested which can decrease the risk of transfusion if platelets/plasma from donors with minor incompatibbility are used.

Key words: Bangabandhu Sheikh Mujib Medical University (BSMMU), Hemolytic Transfusion Reaction (HTR), Hemolytic Disease of Newborn (HDN), World Health Organization (WHO), Direct Antiglobulin Test (DAT).

\section{Introduction}

Transfusion medicine deals with that part of health care system which undertakes the appropriate provision and use of human blood resources. It provides the essential scientific clinical information for transfusion practice and they link between the blood donor altruistic donation and recipients. ${ }^{1}$ An antigen or certain substance present on red cell reacts with corresponding antibody present in the serum can cause harmful effect. ${ }^{2}$ Antibodies that are produced after exposure to foreign antigens are termed as alloantibodies, whereas

1. Medical Officer of Transfusion Medicine, Bangabandhu Sheikh Mujib Medical University (BSMMU).

2. Assistant Professor of Transfusion Medicine, BSMMU.

3. Medical Officer of Transfusion Medicine, BSMMU.

4. Professor of Transfusion Medicine, Dhaka Medical College Hospital.

5. Student of MD (Final part) Transfusion Medicine, BSMMU.

6. Medical Officer of Transfusion Medicine, BSMMU.

7. Professor \& Chairperson of Transfusion Medicine, BSMMU.

Correspondence: Dr. Fatema Easmin, Medical Officer of Transfusion Medicine, Bangabandhu Sheikh Mujib Medical University (BSMMU). those that are produced against self antigens are known as auto antibodies.

Antibodies are globulins which are produced in response to an antigenic stimulation There are five classes of immunoglobulin: IgM, IgG, IgA, IgD, and IgE, of which, only the first two are important in blood transfusion. Red cell antibodies of the IgA class appear rarely and then almost invariably together with IgM and IgG antibodies. ${ }^{2}$ Naturally occurring red cell antibodies are found in a person who has never received blood or blood product, or vaccines of human origin or has never been pregnant nor undergone organ transplantation. This may arise through one of two mechanism. First it seems possible that some immunocompetent cells may be capable of producing a specific antibody in the absence of an antigenic stimulus, secondly the antibodies may be produced in response to substances present in the environment and antigenically similar to blood group antigens. ${ }^{2}$

Immune antibodies arise as a result of exposure to an alloantigen by transfusion of blood products, pregnancy, 
vaccination with vaccines of human origin or transplantation. The antibody that activates complement leading to cell lysis is called hemolysin antibody. Group “ $\mathrm{O}$ ’ donor’s plasma may contain potent anti A or anti-B, capable of reacting with the red cells of a group $\mathrm{A}, \mathrm{B}$ or $\mathrm{AB}$ recipent and sometimes cause a severe transfusion reaction. The anitbodies may take the form of high titre agglutinins or hemolysins. Patient's blood group A, B of AB receiving “01” blood with a high titreIgG anti-A or anti-B reacting at $37^{\circ} \mathrm{C}$ donated by a high risk universal donor may experience a moderate transfusion reaction resulting jaundice and progressive anemia. Immune anti-A and anti-B are sometimes responsible for transfusion reaction following administration oflarge amounts of blood products. $^{3}$

Hemolytic disease of the newborn is the results of red cell alloimmunization in which IgG anybodies passage from the maternal circulation across the placenta in the circulation of the fetus where they react with fetal red calls and lead to their destruction. Anit-D anibody is responsible for most cases of severe HDN although anti-C, anti-E anti-K \& a wide range of other antibodies are found in occasional cases. Although antibodies against the ABO blood group system the most frequent causes of HDN this is usually mild. Within the UK, approximately 500 fetuses develop hemolytic disease each year \& approximately 30 of these cases are fatal. ${ }^{4}$

Previously transfusion/donation/administration of blood group " 0 " to any patient, was considered to be of risk \& a safer option. In the early years of the Second World War group “ $O$ ' blood was use for all emergency transfusion in the European Countries, usually without any cross matching or other serological testing \& adverse reactions were rare.

However, this perception has now recently come to a halt. It is now known that though the recipients serum may not react with the donor's red cells, group “O” donor's plasma may contain potent anti-A or anti-B, capable of reacting with the red cells of a group A, B or Ab recipient and some time can also causes severe transfusion reaction. ${ }^{5}$

The present study was undertaken to investigate the possible differences at various titer level between two sex groups.

\section{Methods:}

This cross sectional study was done on 100 cases of " $O$ ' blood group female inchild bearing age and 100 adult male was selected as control, in transfusion medicine department, BSMMU from June 2008 to May 2009.Detailed demographic and clinical finding of all subject were recorded in data collection sheet. All analysis was done using SPSS (statistical package for social science) using inclusion \& exclusion criteria. The objectives of the study along with its procedure risk and benefits of the study were explained to the subjects in easily understandable local language and then informed consent was taken from each subject. Itwas assured that all information and records would be kept confidential and the procedure would be helpful for both the attending subjects in making rational approach of the case management.

\section{Results \& Observation}

Table-I

Age distribution of the study subject $(n=200)$

\begin{tabular}{lccccc}
\hline Age in Years & \multicolumn{2}{c}{ Female } & \multicolumn{2}{c}{ Male } & P Value \\
& $\mathrm{N}$ & $\%$ & $\mathrm{~N}$ & $\%$ & \\
\hline $18-30$ & 67 & 67.0 & 26 & 26.0 & \\
$31-40$ & 31 & 31.0 & 52 & 52.0 & \\
$41-51$ & 2 & 2.0 & 22 & 22.0 & \\
Mean \pm SD & $27.34 \pm 6.7$ & $35.64 \pm 6.72$ & $0.001^{\mathrm{s}}$ \\
\hline
\end{tabular}

The mean age was 27.34 years with standard division of mean (SD) \pm 6.7 years and their age ranged from 18 to 50 years in female group. In male group the mean age was 35.64 years with standard division of mean (SD) \pm 6.72 years and their age ranged from 20 to 51 years. Maximum number was found in the age group of 20-30 years in female group and 31-40 years in male group. The mean age difference was found statistically significant $(p<.0 .05)$ between female and male in unpaired t-test. The results are shown in the table I.

Table -II

Sex distribution of the study subjects $(n=200)$.

\begin{tabular}{lcc}
\hline Sex & Number of Patients & Percentage \\
\hline Female & 100 & 50.0 \\
Male & 100 & 50.0 \\
\hline
\end{tabular}

This study was carried out in 200 subjects. They were divided into female and male groups. Out of which 50.0\% were female and rest $50.0 \%$ were male subjects.

Table-III

“O” Blood group of the study subject $(n=200)$

\begin{tabular}{lccccc}
\hline $\begin{array}{l}\text { Blood Group } \\
\text { “O” }\end{array}$ & \multicolumn{2}{c}{ Female } & \multicolumn{2}{c}{ Male } & P Value \\
\hline Rh+ve & $\mathrm{N}$ & $\%$ & $\mathrm{~N}$ & $\%$ & \\
Rh-ve & 81 & 81.0 & 98 & 98.0 & $0.003^{\mathrm{s}}$ \\
\hline
\end{tabular}

$\mathrm{S}=$ Significant 
It was found that $81(81.0 \%)$ had $\mathrm{Rh}+\mathrm{ve}$ and $19(19.0 \%)$ had Rh-ve in female subjects, however in male subjects 98(98.0\%) had Rh+ve and only 2(2.0\%) had Rh-ve. The difference was found statistically significant $(\mathrm{p}<0.05)$ between female and male in chi squire test.

Table-IV

Blood group of husband $(n=74)$

\begin{tabular}{lcc}
\hline Blood Group & \multicolumn{2}{c}{ Female } \\
& Number of Patients & Percentage \\
\hline A & 20 & 27.0 \\
B & 21 & 28.4 \\
O & 33 & 44.6 \\
Rh+ve & 22 & 29.7 \\
\hline
\end{tabular}

It was found that 20(27.0\%) husband's had blood group A, 21 (28.4\%) blood group B, 33 (44.6\%) blood group O and among them 22(29.7\%) had Rh+ve.

Table-V

History of blood transfusion of the study subject $(n=200)$

\begin{tabular}{lccccc}
\hline History of Blood & \multicolumn{2}{c}{ Female } & \multicolumn{2}{c}{ Male } & P Value \\
Transfusion & $\mathrm{N}$ & $\%$ & $\mathrm{~N}$ & $\%$ & \\
\hline Yes & 45 & 45.0 & 2 & 2.0 & $0.001^{\mathrm{s}}$ \\
No & 55 & 65.0 & 98 & 98.0 & \\
\hline
\end{tabular}

$\mathrm{S}=$ Significant

It was found that $45(45.0 \%)$ and only $2(2.0 \%)$ had history of blood transfusion in female and male subjects respectively. The difference was found statistically significant $(\mathrm{p}<0.05)$ between female and male in chi square test.

\section{Table-VI}

Parity of the subject $(n=74)$.

\begin{tabular}{lcc}
\hline Para & Number of Patients & Percentage \\
\hline 0 & 54 & 54.0 \\
1 & 22 & 22.0 \\
2 & 20 & 20.0 \\
3 & 3 & 3.0 \\
4 & 1 & 1.0 \\
\hline
\end{tabular}

Nulliparity was predominant in the study subjects.
Table-VII

History of exchange transfusion of babies $(n=20)$

\begin{tabular}{llc}
\hline History of & \multicolumn{2}{c}{ Female } \\
\cline { 2 - 3 } exchange transfusion & $\mathrm{N}$ & $\%$ \\
\hline Yes & 30 & 30.0 \\
No & 70 & 70.0 \\
\hline
\end{tabular}

It was found that $30(30.0 \%)$ had history of exchange transfusion of babies in female.

Table-VIII

Day of appearance of jaundice $(n=100)$

\begin{tabular}{lcc}
\hline Day of appearance & \multicolumn{2}{c}{ Female } \\
\cline { 2 - 3 } & $\mathrm{N}$ & $\%$ \\
\hline 0 & 4 & 4.0 \\
1 & 6 & 6.0 \\
2 & 26 & 26.0 \\
3 & 1 & 1.0 \\
No appearance & 63 & 63.0 \\
\hline No appearance was predominant in the female study subject.
\end{tabular}

Table-IX

Hemolysin test status $(n=200)$

\begin{tabular}{lcccc}
\hline Lab Test Hemolysin & \multicolumn{2}{c}{ Female } & Male \\
test & $\mathrm{N}$ & $\%$ & $\mathrm{~N}$ & $\%$ \\
\hline +ve & 94 & 94.0 & 8 & 8.0 \\
-ve & 6 & 6.0 & 92 & 92.0 \\
\hline
\end{tabular}

It was found that 94(94.0\%) and 8(8.0\%) had Hemolysin test $(+)$ ve in female and male subject respectively.

Table-X

Distribution of hemolysin antibody of the study subject $(n=200)$

\begin{tabular}{lcccc}
\hline $\begin{array}{l}\text { Test of Hemolysin } \\
\text { antibody }\end{array}$ & $\mathrm{N}$ & $\%$ & $\mathrm{~N}$ & $\%$ \\
\hline $\begin{array}{l}\text { Hemolysin antibody with A cell } \\
8\end{array}$ & 24 & 24.0 & 12 & 24.0 \\
16 & 51 & 51.0 & 26 & 52.0 \\
32 & 17 & 17.0 & 10 & 20.0 \\
64 & 8 & 8.0 & 2 & 4.0 \\
Hemolysin antibody with B cell & & & \\
8 & 15 & 15.0 & 15 & 30.0 \\
16 & 50 & 50.0 & 26 & 52.0 \\
32 & 17 & 17.0 & 9 & 18.0 \\
64 & 18 & 18.0 & 0 & 0.0 \\
\hline
\end{tabular}


Most of the Hemolysin antibody with A cell was 16, which were $51(51.0 \%)$ in female and $26(52.0 \%)$ in male group. Similarly majority of the Hemolysin antibody with B cell was 16 which were 50(50.0\%) and 26 (52.0\%) in female and male group respectively.

Table-II

Mean distribution hemolysin antibody of the study subject $(n=200)$

\begin{tabular}{lccc}
\hline $\begin{array}{l}\text { History of Blood } \\
\text { Transfusion }\end{array}$ & $\begin{array}{c}\text { Female } \\
\text { Mean } \pm \text { SD }\end{array}$ & $\begin{array}{c}\text { Male } \\
\text { Mean } \pm \text { SD }\end{array}$ & $\begin{array}{c}\mathrm{P} \\
\text { value }\end{array}$ \\
\hline $\begin{array}{l}\text { Hemolysin antibody } \\
\text { with A cell }\end{array}$ & $21.3 \pm 17.9$ & $19.2 \pm 12.3$ & $0.460^{\text {ns }}$ \\
$\begin{array}{l}\text { Hemolysin antibody } \\
\text { with B cell }\end{array}$ & $26.9 \pm 21.4$ & $16.5 \pm 8.15$ & $0.001^{\text {s }}$ \\
\hline
\end{tabular}

$\mathrm{S}=$ Significant, NS=Not Significant

The mean Hemolysin antibody with A cell and Hemolysin antibody with B cell were $2.13+12.3$ and $16.5+8.15$ respectively. Then mean Hemolysin antibody with A cell and Hemolysin antibody with B cell were found statistically significant $(\mathrm{p}<0.05)$ between female and male in unpaired t-test.

\section{Discussion}

This cross sectional study was carried out with an objective to find out thehemolysin titer of “ $\mathrm{O}$ ' blood group female and determination of significant titer range which indicate risk of hemolyitc disease of newborn.

A total of 200 healthy subject age ranged from 18 to 51 years were included in the study, in the department of transfusion medicine, in BSMMU, during the period June 2008 to May 2009.

In the present study the mean age was $27.34 \pm 6.7$ years with their age ranged from 18 to 50 years in female group. In male group the mean age was $35.64 \pm 6.72$ years with their age ranged from 20 to 51 years. Maximum number was found in the age group of 20-30 years in female group and 31-40 years in male group. The mean age difference was found statistically significant $(p<0.05)$. Aubert etal. $(1942)^{6}$ showed identical age ranged in their study, which is comparable with the present study.

In the current study male ratio 1:1 which is almost consistent with Adewuyi, Gwanzura and Mvere (1994), ${ }^{7}$ where they observed female male ration was 1:14. Regarding the marital status in this study $74.0 \%$ and $84.0 \%$ female and male were married respectively.

It was found in this study that $81.0 \%$ \& $98 \%$ had $\mathrm{Rh}+\mathrm{ve}$ in female and male subjects respectively, which indicates thatRh+ve was significantly $(\mathrm{p}<0.05)$ higher in male subjects.

In this study it was observed that $27.0 \%$ husband's had blood group A, 28.4\% blood group B, 44.6\% blood group O and among them $29.7 \%$ had Rh+ve. About a half (45.0\%) and only $2.0 \%$ had history of blood transfusion in female and male subjects respectively. The history of blood transfusion was significantly $(\mathrm{p}<.05)$ in female subjects.

The mean systolic and diastolic blood pressure was $115.1+15.68 \mathrm{mmHg}$ and $73.23+14.7 \mathrm{mmHg}$ respectively in female group. In male subjects the mean systolic and diastolic blood pressure was $121.4+10.88 \mathrm{mmHg}$ and $80.0+16.2$ mmHg respectively. The mean blood pressure was significantly $(\mathrm{p}<0.05)$ higher in male subjects.

Most of the Hemolysin antibody with A cell and Hemolysin antibody with B cell were 16 and 16 respectively in female and male group.

In this study the mean Hemolysin antibody with A cell and Hemolysin antibody with B cell were 21.3 \pm 17.9 and $26.9+21.4$ respectively in female group. In male group Hemolysin antibody with A cell and Hemolysin antibody with B cell were $19.2 \pm 12.3$ and $16.5+8.15$ respectively. The mean Hemolysin antibody with A cell and Hemolysin antibody with B cell were found significantly $(\mathrm{p}<0.05)$ higher in female subject then male due to pregnancy hymolysin antibody.

\section{Conclusion}

It is important to avoid transfusion of blood containing high titres of immune anti A and anti B antibodies to non $\mathrm{O}$ group recipients. As per the requirements of the American Association of Blood Banks (AABB) Standards transfusion service should have a policy concerning transfusion of components containing significant amounts of ABO incompatible antibodies. Taking into consideration the finding of the present study that strongly heamolytic samples have high titres of IgG, a simple screen for donor heamolysin is suggested which can decrease the risk of transfusion if platelets/plasma from donors with minor incompatibbility aresused. Besides detecting strong heamolytic serum, the test also identifies donor who are likely to have high levels of IgG anti A and/or anti B for blood transfusion purposes.

\section{Conflict of Interest: None}

\section{References}

1. Global blood safety initiative, WHO, Geneva, Swetzerland. 199:3.

2. Brank Bc, Millica B, Manual of Clinical Blood transfusion, $1^{\text {st }}$ edition, UK Churchill Livingstone-1, Longman Groups Ltd. 1986:4.

3. Mollision PL. Blood transfusion in clinical medicine, $10^{\text {th }}$ edition, UK, Blackwell Science, 1997:460.

4. Hoffbrand AV, Essential Haematology, $4^{\text {th }}$ Ed. UK, Blackwell Science, Oxford. 2001:356.

5. Haramening DM, Blood Banking and Transfusion Practice, $3^{\text {rd }}$ Ed, ( $3^{\text {rd }}$ Edition, Maryland USA), JP Brothers, $1^{\text {st }}$ India edition: 64 .

6. Abuert EF, Boorman KE, Dodd BE and Loutit JF, The universal donor with high titre ISO-Agglutinins, British Medical Journal. 1942;30:659-664.

7. Adewuyia JO, Gwanzura C and Mvere D. Characteristics of Anit-A and Anti-B in Black Zimbabweans, Vox Sang. 1994;67:307-309. 